\title{
Evidence for birch bark tar use as adhesive and decorative element in Early Iron Age central
}

\section{Italy: technological and socio-economical implications}

\author{
Lionello Morandi ${ }^{1}$, Simone Porta ${ }^{2,3}$, Erika Ribechini ${ }^{3}$
}

'Department of Archaeology, University of Reading, Whiteknights, RG6 6AB, Reading, UK

\section{${ }^{2}$ museo d'Arte e Scienza.......}

${ }^{3}$ Department of Chemistry and Industrial Chemistry, University of Pisa, via Giuseppe Moruzzi 13, I56124, Pisa, Italy

\begin{abstract}
Archaeological excavations carried out in Early Iron Age Vetulonia (northern Tuscany, Italy) brought to light a funerary urn particularly noteworthy for the presence of an unusual decoration obtained by plastering the vase surface with an organic dark grey substance, on which metal strips were originally fixed. In order to reveal the origin of such organic substance, it was chemically studied by gas chromatography coupled with mass spectrometry (GC/MS). Chemical analysis not only revealed that birch bark tar was used as coating/adhesive material for the manufacture of the urn, but also allowed us to discuss the significance of the vessel in terms of eco-technological knowledge and possible cultural connections on a large geographical scale.
\end{abstract}




\section{Introduction}

The site of Vetulonia $\left(42^{\circ} 51^{\prime} 34^{\prime \prime} \mathrm{N} 10^{\circ} 58^{\prime} 16^{\prime \prime} \mathrm{E}, 335 \mathrm{a} . \mathrm{s} . \mathrm{I}\right.$.) lies on a low hill north of the plain of Grosseto, on the right side of the river Bruna, about $12 \mathrm{~km}$ from the shore of the Tyrrhenian Sea (Curri 1978) (Fig. 1). The settlement bears traces of Final Bronze Age occupation (c. 10th century BC), and increases notably during the Early Iron Age (c. 9th-8th century BC) (Cygielman 1994). At this time, six extensive urnfields including up to 800 cremation burials stretched over the hillslopes around the village. The cremated bones of one or two deceased were usually collected in a ceramic biconical ossuary, which was then placed in a pit dug in the ground and sealed by a slab (Falchi 1891).

The urn under investigation was found in the western graveyard of Colle Baroncio (Fig. 1), excavated during the late 19th century. It is particularly noteworthy for the presence of an unusual decoration obtained by plastering the vase surface with a dark grey substance, on which metal strips, that have now detached leaving only an imprint, were originally fixed (Morandi 2013) (Fig.

2). These thick patches of material applied onto the vessel have no parallels in the contemporary archaeological record of the region. Although several other cases of Early Iron Age tin-band decorated pots are known from sites of Villanova culture of central Italy (Stjernquist 1960), glue is always and only applied directly under the metal strips and does not form a visible part of the decoration (Mazzeo and Sfrecola1989; Morandi 2013). So far, the only available data from pyrolysis-gas chromatography analysis of the adhesives present on these vessels has pointed to the use of bitumen (Mazzeo and Sfrecola 1989).

The aim of this paper is to investigate the nature of the material applied onto the vessel as adhesive and decoration. In particular, its chemical composition was investigated by gas chromatography/mass spectrometry (GC/MS) following alkaline hydrolysis, solvent extraction and trimethylsilylation. The chemical characterisation of organic materials from archaeological excavations can give us very precious information on the array of natural substances exploited by ancient population in everyday life as well as improve our understanding of ancient knowledge and technology. 
In addition, a discussion of the significance of our results in terms of eco-technological knowledge and possible cultural connections on a large geographical scale is also provided.

\section{Materials and methods}

The dark grey substance was sampled from different points of the urn to assure that our chemical investigation was representative. In particular, four micro-samples (a few milligrams) were collected with a scalpel from the external coating of the vessel (two samples were from the body , one from the neck and the last from the handle) (see Figure 2) and preserved in glass vials up to the chemical analysis.

All solvents were Carlo Erba (Milan, Italy) pesticide analysis grade. $n$-hexadecane (internal standard, IS 1 ), tridecanoic acid, (internal standard, $\mathrm{IS}_{2}$ ), hydrochloric acid $(\mathrm{HCl})$, potassium hydroxide $(\mathrm{KOH})$, hexamethyldisilazane (HMDS) and N,O-bis(trimethyl)silyltrifluoro-acetamide (BSTFA) containing 1\% trimethylchlorosilane, were purchased from Sigma Aldrich (Milan, Italy).

The analytical procedure used to investigate the soluble and saponifiable components (Ribechiniet al. 2011)can be summarized as follows: the sample (1-3 mg) was subjected to alkaline hydrolysis by adding $1 \mathrm{ml}$ of hydro-alcoholic $\mathrm{KOH}$ (KOH in $\mathrm{CH}_{3} \mathrm{OH}$ (10\% weight)/ $\mathrm{KOH}$ in $\mathrm{H}_{2} \mathrm{O}$ (10\% weight), 2:3), and heating at $60^{\circ} \mathrm{C}$ for $3 \mathrm{~h}$. After hydrolysis, neutral organic components were extracted with $n$-hexane $(3 \times 500 \mu \mathrm{l})$ and, after acidification with hydrochloric acid (10 M; to $\mathrm{pH} 2)$, the acidic organic components were extracted with diethyl ether $(3 \times 500 \mu l)$. The $n$-hexane and ether fractions were mixed, evaporated to dryness under a gentle stream of nitrogen and subjected to trimethylsilylation. This was achieved by mixing the dried aliquots with a derivatization internal standard solution (5 $\mu \mathrm{l}$ of tridecanoic acid solution) and then they were derivatised with $20 \mu \mathrm{l}$ of BSTFA (at $60^{\circ} \mathrm{C}, 30 \mathrm{~min}$ ), using $150 \mu \mathrm{l}$ iso-octane as the solvent. $2 \mu \mathrm{l}$ of the solution were analysed by GC/MS.

For the gas chromatographic separation, a 6890N GC System Gas Chromatograph (Agilent Technologies) coupled with a 5975 Mass Selective Detector (Agilent Technologies) single quadrupole mass spectrometer equipped with a PTV injector was used. The PTV injector was equipped with a glass PTV liner (multi baffle, deactivated, $1.5 \mathrm{~mm}$, Agilent Technologies). The 
mass spectrometer was operated in El positive mode (70 eV, scanning m/z 50-700). The MS transfer line temperature was $280^{\circ} \mathrm{C}$; the MS ion source temperature was kept at $230{ }^{\circ} \mathrm{C}$ and the MS quadrupole temperature at $150^{\circ} \mathrm{C}$. For the gas chromatographic separation, an HP-5MS fused silica capillary column (5\%diphenyl-95\%dimethyl-polysiloxane, $30 \mathrm{~m} \times 0.25 \mathrm{~mm}$ i.d., $0.25 \mu \mathrm{m}$ film thickness, J\&W Scientific, Agilent Technologies, Palo Alto, CA, USA) coupled with a deactivated silica pre-column ( $2 \mathrm{~m} \times 0.32 \mathrm{~mm}$ i.d., J\&W Scientific Agilent Technologies, Palo Alto, CA, USA) using a quartz press fit (press-fit connector $0.32 \mathrm{~mm}$ to $0.25 \mathrm{~mm}$, Agilent Technologies, Switzerland), was used. The PTV injector was used in splitless (purge valve time 0.7 min) mode at $280^{\circ} \mathrm{C}$. The chromatographic conditions were programmed as follows: $80^{\circ} \mathrm{C}$, isothermal for $2 \mathrm{~min}$, $10^{\circ} \mathrm{C} / \mathrm{min}$ up to $200^{\circ} \mathrm{C}, 200^{\circ} \mathrm{C}$, isothermal for $3 \mathrm{~min}, 10^{\circ} \mathrm{C} / \mathrm{min}$ up to $280^{\circ} \mathrm{C}, 280^{\circ} \mathrm{C}$, isothermal for $3 \mathrm{~min}, 20^{\circ} \mathrm{C} / \mathrm{min}$ up to $300^{\circ} \mathrm{C}$, and $300^{\circ} \mathrm{C}$, isothermal for $30 \mathrm{~min}$. The carrier gas was used in the constant flow mode (He, purity $99.9995 \%)$ at $1.2 \mathrm{ml} / \mathrm{min}$.

\section{Results}

Fig. 3 shows the chromatogram acquired by GC/MS of the sample collected from the handle. For the other samples, similar chromatographic profiles were obtained. Triterpenoids with a pentacyclic skeleton and lupane type structure such as betulin, lupeol, lupadienol and betulone are among the main chemical constituents of the samples. In addition, a series of linear $\alpha, \omega$-dicarboxylic acids ranging from 16 to 22 carbon atoms and of a series of $\omega$-hydroxycarboxylic acids ranging from 18 to 22carbon atoms are also evident.Lupane type molecules, and long chain $\alpha, \omega$-dicarboxylic acids and $\omega$-hydroxycarboxylic acids are considered as characteristic of the tar from the barkof the tree family Betulaceae (Colombiniet al. 2006; Mazzaet al. 2006; Ribechiniet al. 2015). The analysis of the chemical composition of the dark grey substance from the vessel revealed also the presence of 12-hydroxy-octadecanoic acid, the saturated form of ricinoleic acid, leading to the hypothesis that a conservation product was employed in the course of the restoration of the vessel. 12-hydroxyoctadecanoic acid along with octadecanoic and hexedecanoic acids are the main components of hydrogenated castor oil known as castor wax, a product used in formulation also with other substancesin conservation science. 
Tar and pitch are black sticky substances obtained by hard-heating treatments and destructive distillation-type processes either of wood, bark, or resin from soft and hardwood trees such as pine, spruce and birch.Neanderthal- and human-made birch bark tar has been produced since the lower Palaeolithic (Colombiniet al. 2006; Mazzaet al. 2006), given the variety of purposes for which this substance can be used (Koller and Mania 2001). Frequently employed as a glue for hafting artefacts, tar is also a good waterproofing and sealing material, as well as having medicinal properties (Aveling and Heron 1999; Regert 2004). It can be obtained by heating between $300^{\circ} \mathrm{C}$ and $400^{\circ} \mathrm{C}$ two superimposed pots (double-pot method), the upper one being filled with bark, that will progressively burn off dripping down the liquid components (Hayek et al. 1990; Kurzweil and Totenhaupt 1990; Dudd and Evershed 1999; Piotrowski 1999; Pawlik and Thissen 2011) into the lower pot. Once collected, tar can be brought to the boil to evaporate the volatile fraction, obtaining a more viscous substance. Earth-dug furnaces were probably used in pre-ceramic contexts, where reaching and maintaining the necessary temperature must have required an excellent fire control (Groom et al. 2015).

\section{Discussion}

The making of a metal-band decorated ceramic vessel coated with birch bark tar in Early Iron Age Vetulonia reveals the existence of a productiveprojectbringing together different technological know-hows, presumably possessed by different individuals. In order achieve the finaloutcome a complex operational sequence is necessary, involving procurement and processing of different raw materials (clay, tin, birch bark) (Fig. 4).

Little is known about the organization of ceramic workshops in Early Iron Age Etruria, but it is likely that a degree of specialism comparable to Peacock's 'individual/nucleated workshops' had already been reached (Peacock 1982; Boitani et al. 2009; Morandi 2013). Tin smelting was presumably carried out in bronze workshops, where slags could be melted to obtain tin sheets that were cut into narrow strips used for tin-band decorated pottery (Stjernquist 1960). The most likely location of the tin ore used in Vetulonia lies on the Colline Metallifere, about $40 \mathrm{~km}$ northwest of the settlement (Nannoni and Sammartino1997; Lehoërff 2007). As for birch bark tar, there is no evidence to date 
of tar-impregnated vessels used for the double-pot method in Early Iron Age Etruria. However, the archaeological record of the region in this period is largely funerary, and alternative methods using earth-dug pits may have been used even in ceramic contexts (Pawlik and Thissen 2011). Villanovan impasto ware was mostly fired in earth-dug furnaces (Boitaniet al. 2009), so that a high competence with this baking method will have enabled accurate temperature control and consequent tar extraction (Groom et al. 2015). As birch bark tar can be also used to repairvases (Hayek et al. 1990), it is likely that potters were able to obtain it upon necessity and therefore possessed the necessary know-how.

Our find is a rare example of birch bark tar-coated pottery from a funerary context. Lucquinet al. (2007) stressed the possible ritual value of birch bark tar from a Neolithic grave, given its odoriferous properties. In our case, it is likely that the choice of plastering a large portion of the vessel with tar was intentional, due to the chromatic contrast between dark-coloured tar and silvercoloured tin strips (Fig.5).

The identification of birch bark tar plastered on this vasealso opens new scenarios and research questions in relation to the extraction, usage and economic value of this product in proto-Etruscan settlements of the early 1st Millennium BC. Moreover, this is to date the southernmost evidence of archaeological birch bark tar in continental Europe.

A first consideration concerns the rarity of Betula spp. in the area. Betula spp. are typically EuroSiberian taxa dominating boreal forests, which in the Late Holocene have characterised the landscape of north central Europe. The genus Betula (Betulaceae family) is represented in Europe by three species: $B$. pendula, $B$. pubescens and $B$. nana. These latter are typically boreal species, with $B$. pendula being the most common species diffused at southern latitudes. $B$. pendula is a typical heliophilous pioneer tree, capable of rapidly colonising open areas whenever it finds suitable conditions, such as acid sandy-pebbly soils, relatively moderate summer temperatures and high moisture (Plini and Tondi 1989; David and Barbero 1995) In Italy, Betula spp. find a favourable environment in the Alps and Prealps, but in view of the elevated temperatures of the Apennines compared to the Alps and prolonged summer drought, north central Italy marks the southern limit of the current distribution of Betula spp. in the peninsula (with a few exceptions in 
Campania and Sicily) (Plini and Tondi 1989). B. pendula is reported only from four sites in Tuscany, and in some cases it is not certain whether or not it occurred naturally in the region (Plini and Tondi 1989). Pollen diagrams from Lago dell'Accesa (c. $15 \mathrm{Km}$ from Vetulonia) (DrescherSchneider et al. 2007) show very low values of birch during the Holocene, pointing to long-distance transportation of grains, perhaps from the hills of the pre-Apennines. In any case, it is likely that after the Last Ice Age, Betula spp. have always been rare taxa in Tyrrhenian central Italy.

In view of the above, some birch specimens may have been present in wood patches on the Apennines and pre-Apennines. It is therefore possible that the inhabitants of Vetulonia organised relatively long journeys to harvest birch bark for extracting tar for multiple purposes, as suggested for Early Iron Age Corsica (Rageotet al. 2016). On the other hand, in view of complementary archaeological evidence, it cannot be ruled out the possibility that birch bark,or birch bark tar as a ready-to-use product, reached Vetulonia (and presumably other contemporary settlements) through a system of long-distance exchange and trade of raw matter and valuable goods.

It is known that routes connecting the Baltic area to northern Italy were already established by the Middle Bronze Age, in view of the increasing importance of amber trade. Baltic amber (succinite) becomes the by far more common variety of amber in southern Europe (Colombiniet al. 2013), and reaches the Terramare area (Po plain) and the fringes of the Tosco-Emilian Apennines in the Middle/Late Bronze Age (c. 1600-1150 BC) following the 'central route' (de Navarro 1925; de Marinis 2007; Miari 2007; Bellintani 2014). The main amber route will then shift eastwards during the Final Bronze Age (c. 1150-900 BC), when amber is still found in the Padanian region at Bismantova (de Marinis 2006; Bellintani 2014). Amber objects are then present a few decades later in Early Iron Age urnfields of Vetulonia (Poggio alla Guardia, graves 45, 61, 132, 140) andBologna, the major Early Iron Age settlement in the Po plain, as well as in several other Tyrrhenian settlements of central Italy (Populonia, Tarquinia, Veii) (Falchi 1885; Pasqui 1885; Pincelli and MorigiGovi 1975). Connections between Vetulonia, other Villanovan settlements and the contemporary centre of Bologna in the Padanian area are indicated by the distribution of a few particular metal and pottery types. Bronze bow-fibulae of rhomboidal cross section are found in the mining district of Tuscany and in the Po plain, shedding light on the routes followed by isolated 
individuals or specialised metalworkers (Morandi 2013). Among the ceramic assemblages, similar connections pointing to the existence of established routes between Etruria and Padania are suggested by boot-shaped vases (Bologna, Vetulonia, Veii) and funerary vessels with four projections (Bologna and Vetulonia) (Cygielman 1994). These connections are long-lasting, as one century later Vetulonia will still show established contacts with northern Italian settlements (Gambari 1986), and will share similarities in the material culture with Verucchio, a major centre for Baltic amber working near the Adriatic coast (von Eles2009).

This is not surprising, as contacts on a much larger scale between Tyrrhenian central Italy and northern Europe around $800 \mathrm{BC}$ are shown by the remarkable finding of a specific decorated type of laminated bronze amphoraeinsouthern Etruria,central Europe and Scandinavia (Jockenhövel 1974; Kristiansen 1993; laia 2005,2006). Either these products are imported or imitated by local artisans, they show the existence of long-range connections, probably due to the presence of itinerant specialised craftsmen travelling between elite centres.A possible relationship between metalwork routes and amber routes has been suggested, due to the exploitation of Pomeranian amber sources in the 8th century BC (Kristiansen 1993). In addition to this, high-rank burials from north-central Europe and central Italy show similarities in the funerary ritual, pointing to a common ‘background ideology' which has roots in the Greek Homeric world (Kristiansen 1993,2000).

Along with raw amber and /or amber objects, it is thussuggested that the trade of a much lesser archaeologically visible, but nonetheless useful product such as birch bark tar may have taken place along the same routes, at least since the Early Iron Age. There are several examples of trade of birch tar and other adhesives in antiquity. Birch bark tar trade has been documented in 1st century BC Sweden, where the substance was manufactured and stored in form of loaves (Bergström 2004), and evidence for tar storage is also available for Late Iron Age France (Regertet al. 2003). Long-distance trade of other adhesive materials is known since much earlier periods in the Near East, where bitumen was regularly imported since the 7th Millennium BC (Connan 2010). Birch bark tar in proto-Etruscancentres may therefore have been acquired following established links with boreal regions used for amber trade, or obtained by local specialised craftsmen following the arrival of birch bark from north-central Europe. 
Aside from glue function and medicinal properties, birch bark tar may have been of essential importance for the caulking of wooden boats. Prior to the silting up of the Prilius Lacus, Vetulonia controlled the large brackish lagoon once lying on the plain of Grosseto, which enabled access to the Tyrrhenian Sea (Lutiet al. 2000). Coastal cabotage had probably a remarkable importance for Early Iron Age settlements, and clear and frequent contacts between Vetulonia and Sardinia (Cygielman and Pagnini 2002) also point to the existence of a developed expertise in open-water seafaring by both counterparts during the same period (Mandolesi and Castello 2009; Fundoni 2013).

\section{Conclusions}

The analytical data obtained by GC/MS show that the organic material collected from the external surface of the urn from Vetulonia is a tar obtained submitting birch bark to a pyrolysis-type process. Narrow metal strips were therefore applied to the vase using birch tar as an adhesive, and perhaps also as a decorative element. Birch bark tar extraction implies the existence of a specialised knowledge, either possessed by members of the local community, or by itinerant craftsmen or merchants.

Birch bark may have been purposely collected on the Apennine range, a few tens of $\mathrm{km}$ from the settlement. However, given the rarity of birch in central Italy, archaeological evidence also points to the possibility of birch bark tar acquisitionthrough a wider system of long-distance exchange, involving other goods such as amber and metal objects. Within the context of a proto-urban settlement, this substance would have been useful for a wide range of practical purposes.

\section{Acknowledgements}




\section{References}

Aveling, E. M., and Heron, C., 1999, Chewing tar in the early Holocene: an archaeological and ethnographic evaluation, Antiquity, 73(281), 579-584.

Bellintani, P., 2015, Baltic amber, alpine copper and glass beads from the Po Plain. Amber trade at the time of Campestrin and Frattesina, Padusa, 50(2014), 111-140.

Bergström, L., 2004, The Roman Iron Age Tar Loaf from Albertsro, Sweden-and the Scandinavian Tar loaves of the Bronze Age, Actaarchaeologica, 75(2), 1-13.

Boitani, F., Neri, S., and Biagi, F., 2009, Novità dall'impianto produttivo della prima età del Ferro di Veio-Campetti,I mestieri del fuoco. Officine e impiantiartigianalinell'Italiapreromana, OfficinaEtruscologia, 1, 23-42.

Colombini, M. P., Modugno, and Ribechini, E., 2006, Chemical study of triterpenoid resinous materials in archaeological findings by means of direct exposure electron ionisation mass spectrometry and gas chromatography/mass spectrometry, Rapid Communications in Mass Spectrometry, 20, 1787-1800.

Colombini, M. P., Ribechini, E., Rocchi, M., and Selleri, P., 2013, Analytical pyrolysis with in-situ silylation, Py (HMDS)-GC/MS, for the chemical characterization of archaeological and historical amber objects, Heritage Science, 1, 6.

Connan, J., and Van de Velde, T., 2010,An overview of bitumen trade in the Near East from the Neolithic (c. 8000 BC) to the early Islamic period, Arabian archaeology and epigraphy, 21(1), 1-19. Curri, C. B., 1978, Vetulonia(Vol. I), Firenze.

Cygielman, M. 1994, Note preliminari per una periodizzazione del villanoviano di Vetulonia, in La presenza etrusca nella Campania meridionale, Atti delle giornate di studio(eds. P. Gastaldi and G. Maetzke), 255-292.

Cygielman, M., Pagnini, L., 2002, Presenze sarde a Vetulonia: alcune considerazioni, in Etruria e Sardegna centro-settentrionale tra l'età del Bronzo Finale e l'Arcaismo, Atti del XXI Convegno di Studi Etruschi e Italici, 387-410. 
David, F., and Barbero, M., 1995, De I'histoire du genre Betuladans les AlpesFrançaises du Nord, Review of Palaeobotany and Palynology, 89(3), 455-467.

de Marinis, R. C., 2007, L'ambra in Italia settentrionale tra Alpi e Po durante l'età del Bronzo, in Ambre. Trasparenzedall'antico(eds. M. L., Nava and A. Salerno), 60-67.

de Navarro, J. M., 1925, Prehistoric routes between northern Europe and Italy defined by the amber trade, The Geographical Journal, 66(6), 481-503.

Drescher-Schneider, R., De Beaulieu, J. L., Magny, M., Walter-Simonnet, A. V., Bossuet, G., Millet, L., Brugiapaglia, E., and Drescher, A., 2007, Vegetation history, climate and human impact over the last 15,000 years at Lago dell'Accesa (Tuscany, Central Italy), Vegetation History and Archaeobotany, 16(4), 279-299.

Dudd, S. N., and Evershed, R. P., 1999, Unusual triterpenoid fatty acyl ester components of archaeological birch bark tars, Tetrahedron Letters, 40(2), 359-362.

von Eles, P. 2009, Verucchio: gruppi aristocratici sull'Adriatico dell'età del Ferro, in Sovrani etruschi dei due mari. Tesori d'oro e d 'ambra da Vetulonia e Verucchio (eds. M. Cygielman, M., P. Spaziani and S. Rafanelli), 18-23.

Falchi, I., 1885, Colonna, Notizie degli Scavi di Antichità, 398-417.

Falchi, I., 1891, Vetulonia e la sua necropoli antichissima, Firenze.

Fundoni, G. 2013, Le relazioni tra la Sardegna e la Penisola Iberica tra il Bronzo Finale e la prima età del Ferro attraverso le testimonianze archeologiche (secoli XII-VII a.C.),Córdoba.

Gambari, F. M., 1986, Castelletto Ticino: la tomba del Bacile, in Gli Etruschi a nord del Po(ed. R. C. de Marinis), 81-84.

Groom, P., Schenck, T., and Pedersen, G. M., 2015, Experimental explorations into the aceramic dry distillation of Betulapubescens (downy birch) bark tar, Archaeological and Anthropological Sciences, 7(1), 47-58.

Hayek, E. W., Krenmayr, P., Lohninger, H., Jordis, U., Moche, W., and Sauter, F., 1990, Identification of archaeological and recent wood tar pitches using gas chromatography/mass spectrometry and pattern recognition, Analytical Chemistry, 62(18), 2038-2043.

laia, C., 2005, Produzioni toreutiche della prima età del ferro in Italia centro-settentrionale: stili 
decorativi, circolazioni, significato (Vol. 40), Istituti Editoriali Poligrafici Internazionali.

laia, C., 2006, Prima del "simposio": vasi in bronzo e contesto sociale nell' Etruria meridionale protostorica, Revista d'Arqueologia de Ponent, 16-17, 261-270.

Jockenhövel, A., 1974, Eine Bronzeamphore des 8. Jahrunderts v. Chr. Von Gevelinghausen, Kr. Meschede (Sauerland), Germania, 52, 16-54.

Koller, J., Baumer, U., and Mania, D., 2001, High-tech in the Middle Palaeolithic: Neandertalmanufactured pitch identified, European Journal of Archaeology, 4(3), 385-397.

Kristiansen, K., 1993, From Villanova to Seddin: the reconstruction of an elite exchange network during the eighth century BC, in Trade and exchange in Prehistoric Europe(eds. C. Scarreand F. Healy), 143-54.

Kurzweil, A., andTodtenhaupt, D., 1990, Das Doppeltopf-Verfahren: Eine rekonstruierte mittelalterliche Methode der Holzteergewinnung,Archäologische Mitteilungen aus Nordwestdeutschland, 4, 472-479.

Lehoërff, A., 2007, L'artisanat du bronze enltaliecentrale, 1200-725 avantnotreère: le métal des dépôtsvolontaires, Roma.

Lucquin, A., March, R. J., and Cassen, S., 2007, Analysis of adhering organic residues of two "coupes-à-socles" from the Neolithic funerary site "La HougueBie" in Jersey: evidences of birch bark tar utilization, Journal of archaeological science, 34(5), 704-710.

Luti, R., Pranzini, E., Donati, L., and Aminti, P. L., 2000, Ricerche sul territorio di Roselle per l'individuazione degli approdi dall'età etrusca a quella moderna. Science and technology for cultural heritage, 9(1/2), 1000-1051.

Mazza, P. P. A., Martini, F., Sala, B., Magi, M.,Colombini, M. P., Giachi, G., Landucci, F., Lemorini, C., Modugno, F., Ribechini, E., 2006, A new Palaeolithic discovery: tar-hafted stone tools in a European Mid-Pleistocene bone-bearing bed, Journal of Archaeological Science, 33, 1310-1318.

Mandolesi, A., and Castello, C., 2009, Modellini di navi tirrenico-villanoviane da Tarquinia, Mediterranea 6, 9-28.

Mazzeo, R., and Sfrecola, S., 1989, Indagini chimico-mineralogiche sulle decorazioni a lamelle metalliche, in Tovoli, S., Il sepolcreto villanoviano Benacci-Caprara di Bologna, 299-301. 
Miari, M., 2007, L'ambra in area terramaricola, inAmbre. Trasparenze dall'antico(eds. M. L. Nava and A. Salerno), 68-72.

Morandi, L., 2013, Early Iron Age finds from the Villanovan cemetery of Colle Baroncio:remarks on early Vetulonia and its connections, Meditarch, 26, 1-14.

Morrocchi, D., Chiarucci, A., and De Dominicis, V., 1997, An interesting new finding of Betula pendula Roth in Tuscany, Atti Soc. tosc. Sci. nat., Mem., Ser. B, 104, 35-41.

Nannoni, R., and Sammartino, F., 1997, Miniere e minerali. Cenni sulla geochimica del rame e dello stagno, in Dal bronzo al ferro. Il Il millennio a.C. nella Toscana centro occidentale (ed. A. Zanini), 18-21.

Pasqui, A., 1885, Colonna, Notizie degli Scavi di Antichità, 98-152.

Pawlik, A. F., and Thissen, J. P., 2011, Hafted armatures and multi-component tool design at the Micoquiansite of Inden-Altdorf, Germany, Journal of Archaeological Science, 38(7), 1699-1708.

Peacock, D. P. S., 1982, Pottery in the Roman World, an Ethnoarchaeological Approach, London.

Pincelli, R., and MorigiGovi, C., 1975, La necropoli villanoviana di San Vitale, Imola.

Piotrowski, W., 1999, Wood tar and pitch experiments at Biskupin Museum, in Experiment and Design (ed. A. F. Harding), 148-155.

Plini, P., and Tondi, G., 1989, La distribuzione appenninica della Betulla bianca, Natura e montagna, 36(3-4), 21-28.

Rageot, M., Pêche-Quilichini, K., Py, V., Filippi, J. J., Fernandez, X., and Regert, M., 2016, Exploitation of beehive products, plant exudates and tars in Corsica during the early Iron Age, Archaeometry, 58(2), 315-332.

Regert, M., 2004, Investigating the history of prehistoric glues by gas chromatography-mass spectrometry, Journal of separation science, 27(3), 244-254.

Ribechini, E., Pérez-Arantegui, J., Colombini, M. P., 2011, Gas Chromatography/Mass Spectrometry and Pyrolysis-Gas Chromatography/Mass Spectrometry for the chemical characterisation of modern and archaeological figs (Ficuscarica), Journal of Chromatography A, 1218(25), 3915-3922.

Ribechini, E., Mangani, F., Colombini, M. P., 2015, Chemical investigation of barks from broad- 
leaved tree species using EGA-MS and GC/MS, Journal of Analytical and Applied Pyrolysis, 114, 235-242.

Stjernquist, B., 1960, La decorazione metallica delle ceramiche villanoviane in una nuova illustrazione, in Civiltà del Ferro. Studi pubblicati nella ricorrenza centenaria della scoperta di Villanova (ed. G. De Vergottini), 432-442.

\section{Figure captions}

Figure 1. Map showing the location of Vetulonia (the shore line reflects the geo-morphological situation during the first millennium BC). Bottom image: grey = hypothetical settled area; white $=$ Early Iron Age graveyards (Colle Baroncio encircled by the dashed line).

Figure 2.Vetulonia, cemetery of Colle Baroncio: biconicalurn. Museo Archeologico e d'Arte della Maremma, Grosseto, inventory no. 1310. Sampling locations indicated by the whitedots. (non ancora aggiunti, l'immagine è provvisoria, ne useremo altre migliori, e manca anche la scala)

Figure 3.TIC chromatogram of the hydrolysed and trimethylsilylated sample from the handle of the urn obtained by GC/MS. CX:Y are fatty acids of chain length $x$ and degree of unsaturation $y ; \alpha, \omega$ $\mathrm{C}_{X: Y}$ are $\alpha, \omega$-dicarboxylic fatty acids of chain length $x$ and degree of unsaturation $y ; \omega-O H-C x: y$ are $n$-alkanols of chain length $x$ and degree of unsaturation $y$.

Figure 4. Scheme summarising the stages of the operational sequence necessary to produce the vessel.

Figure 5. Reconstruction of the original appearance of the urn, showing the chromatic contrast between dark tar and silver-colouredtin strips.(l'immagine è provvisoria, questo è solo unoschizzo a matita) 